This item was submitted to Loughborough's Research Repository by the author.

Items in Figshare are protected by copyright, with all rights reserved, unless otherwise indicated.

\title{
An old fashioned banking crisis: credit growth and loan losses in the UK 1997-2012
}

\section{PLEASE CITE THE PUBLISHED VERSION}

http://www.cambridge.org/br/academic/subjects/economics/macroeconomics-and-monetary-economics/ukeconomy-long-expansion-and-its-aftermath?format=HB

\section{PUBLISHER}

Cambridge University Press

\section{VERSION}

AM (Accepted Manuscript)

\section{PUBLISHER STATEMENT}

This work is made available according to the conditions of the Creative Commons Attribution-NonCommercialNoDerivatives 4.0 International (CC BY-NC-ND 4.0) licence. Full details of this licence are available at: https://creativecommons.org/licenses/by-nc-nd/4.0/

\section{LICENCE}

CC BY-NC-ND 4.0

\section{REPOSITORY RECORD}

Milne, Alistair. 2019. "An Old Fashioned Banking Crisis: Credit Growth and Loan Losses in the UK 1997-2012". figshare. https://hdl.handle.net/2134/20544. 


\section{Chapter 5 \\ An Old Fashioned Banking Crisis: Credit Growth and Loan Losses in the UK $1997-2012^{1}$}

Alistair Milne and Justine A. Wood

The goal of this paper is to investigate the role played by new forms of banking and by financial innovation in supporting the expansion of UK domestic credit during the years 1997-2007 and in the subsequent credit losses of 2007-2012. Our conclusion, surprisingly, is that the most important mechanism operating was much the same as during earlier similar episodes in the UK, the secondary banking crisis of 1973-1975 and the property related banking losses of 1991-1993. In all three cases, unsustainable lending secured on property was the main culprit; sometimes but not always this was intermediated via 'shadow' banks outside of the regular banking sector, but this was a characteristic of the 1973-1975 credit expansion just as much as during the final years of the long expansion. Credit derivatives and other financial innovations, and maturity mismatch conducted by non-bank intermediaries, both of which contributed to a rapid growth of so called 'shadow banking' in the US and to subsequent losses on US structured credit securities in recent years, played only a relatively minor role in the UK credit expansion and loan losses of 1997-2012.

Paper prepared for conference:

The Causes and Consequences of the Long UK Expansion: 1992 to 2007 19th - 20th September 2013, Clare College Cambridge

\footnotetext{
${ }^{1}$ We thank Charles Nolan and Stephen Wright for detailed comments.
} 
This is not to say that shadow banking played no role at all in the UK, but this was an 'old' form of shadow banking, different from the 'new' shadow banking that was so prominent in the credit losses and liquidity problems of the US financial system in 2007-2008. The 'new' shadow banking is characterised by substantial maturity mismatch and funding through 'deposit like' liabilities (short term money-like assets, notably shares in money market mutual funds, regarded as entirely safe but without deposit guarantees or the liquidity support provided by direct access to the central bank lender of last resort facility). The 'old' shadow banking consists of non-bank credit providers that rely to an important extent on borrowing from established banks, and where they borrow in money markets do so on an uncollateralised basis (so their liabilities are recognised as relatively risky short term investments, not entirely safe substitutes for bank deposits).

We show that, in contrast to the situation in the US in the run-up to the crisis of 2007-2008, almost all the domestic (i.e. sterling lending) in the UK was extended directly or indirectly by established UK regulated banks and most of the associated risks were retained on their balance sheets. In comparison to the US, shadow banks played and lesser and more conventional role in the form of specialised financial intermediaries, such as REITs and other property investment companies, which borrowed from the established banking sector to finance investment in commercial property; 'new' shadow banks did not significantly compete with the established banks for short term deposit and wholesale sterling funding. The paper is organised a follows. Section 2 reviews the existing literature on shadow banking and its role in the build of up systemic risk before the recent global financial crisis. Section 3 then uses available Bank of England data to examine both the build of credit and subsequent UK sterling banking losses during the years $1997-2013$ and the role of shadow banking in their finance. Section 4 provides a brief comparison with earlier episodes of property related banking losses in the UK in 1973-74 and 1991-1993. Section 5 concludes.

\section{Shadow banking and the global financial crisis}

A substantial recent literature has addressed the role of shadow banking during the global financial crisis of 2007-2008, focussing largely on US experience. There are two reasons for this focus on the US: in the years preceding the crisis a large US dollar 'shadow banking' 
system emerged that played a key role in financing the subprime mortgage lending in the United States. The literature though has largely ignored 'shadow banking' in other currencies, primarily for the reason that data on the structured credit securities and other instruments are much more readily available for the US than for other countries. This section reviews this literature, emphasising the contrast between the way shadow banking has recently operated in the US ('new' shadow banking) with the way in which it has operated in other countries and at other times ('old' shadow banking).

Although most work on shadow banking refers to US experience, there has more recently been a shift in interest to various forms of shadow banking across the world. Beginning in 2011 the Financial Stability Board has published an annual monitor of shadow banking activities, the latest of which covers 20 jurisdictions together with the Euro area (Financial Stability Board 2013). The Financial Stability Board has also, in August 2013, proposed a global approach to the regulation of shadow banking.

\section{‘New’ versus ‘old’ shadow banking}

The Financial Stability Board defines shadow banking as 'credit intermediation involving entities and activities outside the regular banking system.$^{2}$ This broad definition includes, for example, specialised or offshore banks subject to lighter regulation and scrutiny than established banks, as well as non-bank intermediaries. Within this broad definition, it is useful to contrast two characterisations of shadow banking, which we label respectively as the 'new' and 'old'. The new characterisation dominates much of the current research literature (Adrian and Shin 2009; Pozsar et al. 2010; G. B. Gorton and Metrick 2010; Singh 2010; Pozsar and Singh 2011), but we will argue that the experience of the UK which we examine is better characterised as 'old' shadow banking. ${ }^{3}$

Four key features of this 'new' US dollar shadow banking (or rather shadow banking system) are: first and most importantly that it engaged in extensive maturity transformation using

\footnotetext{
2 (Financial Stability Board 2013)

${ }^{3}$ Our distinction between 'old' and 'new' is reflected in the past usage of the term shadow banking. It seems to have been first used to describe what we call 'new' shadow banking by (McCulley 2007), but had previously been used to refer to what we call 'old' shadow banking, for example by (Bradshaw 2004).
} 
liabilities (shares in money market mutual funds) that investors regards as extremely safe and therefore as close substitutes for bank deposits; second that it provided intermediation from ultimate savers (households and companies) right through to ultimate borrowers (a wide range including sub-prime mortgage borrowers and other lending secured on property) entirely outside of the established banking system; third that is operates without the liquidity support provided by access to the lender of last resort facility from the central bank and is thus subject to runs; and fourth and finally that it made extensive use of innovative instruments such as credit derivatives, structured credit securities and various forms of collateralised short term funding, both on and off balance sheet, in order to transform illiquid loans into apparently safe and liquid short term liabilities.

While the recent literature has focused almost exclusively on this 'new' shadow banking and its role in the build up of both credit and liquidity risk in the US over the years 2002-2007, a different and older form of shadow banking has appeared in many other jurisdictions and on previous occasions, making little or no use of the technologies of securitisation, repo and credit derivatives and not perceived as creating liabilities that are a close substitute for bank deposits. In this 'old' form of shadow banking smaller institutions, operating offshore or under looser regulatory oversight than established banks, provide an important share of domestic credit; but this shadow bank lending is funded by some combination of direct lending from established banks and short term unsecured money market borrowing i.e. its short-term liabilities are explicitly recognised as being risky. Frequently these shadow banks satisfy the substantial demand for lending in property booms, providing secured lending on residential and commercial property. Examples of losses arising from this 'old' form of shadow banking include the UK in 1973-75 and 2008-2012 and Thailand in 1997-98. ${ }^{4}$ Other examples go back at least as far as the failure of US trust companies during the panic of 1907.5

To sum up the 'new' US dollar shadow banking that emerged during the years 2002-2007 used structured credit securities as repo collateral for raising short term money market finance, especially from money market mutual funds that captured deposits away from

\footnotetext{
${ }^{4}$ The UK examples are documented later in this chapter. For Thailand see Leightner and Lovell (1998), Alba, Hernandez, and Klingebiel (1999) and Charumilind, Kali, and Wiwattanakantang (2006).

${ }^{5}$ See Moen and Tallman (1992) and Frydman, Hilt, and Zhou (2012)
} 
traditional banks. This in turn allowed credit to be extended directly to borrowers without direct intermediation by banks. The literature on this 'new' shadow banking emphasises the demand for money-like assets i.e. liquid, risk free interest-bearing assets that can be exchanged without requiring costly assessment of their value. But other forms of shadow banking ('old' shadow banking) have emerged at other times and in other jurisdictions, engaged in conventional lending, and funded either directly by banks or with liabilities that were recognised as being riskier than bank deposits.

Figure 1, illustrates the possible links between regular banks, shadow banks and financial market participants. The figure is complicated, a reflection of the great variety both in the ways in which shadow banks can be funded and in assets they hold. As we have described the 'new' shadow banking that emerged in US dollar markets in the years 2002-2007 was characterised by (a) the holding of securities, especially short term paper and structured credit securities; and (b) using these securities obtain collateralised money market funding either from money market mutual funds or from long only institutional investors. These links are thus illustrated in the figure by the linkages contained with the dotted circle: the 'new' shadow banking nexus.

This configuration can be contrasted with the case of the UK during the period 2003-2009as illustrated by the dashed lines in Figure 1 and documented in our Section 3 below. In the UK in these years sterling shadow banking was primarily funded directly by traditional deposit and credit institutions, not from money markets; and these UK shadow banks made relatively little use of structured credit instruments, rather they mostly provided credit directly to borrowers. 


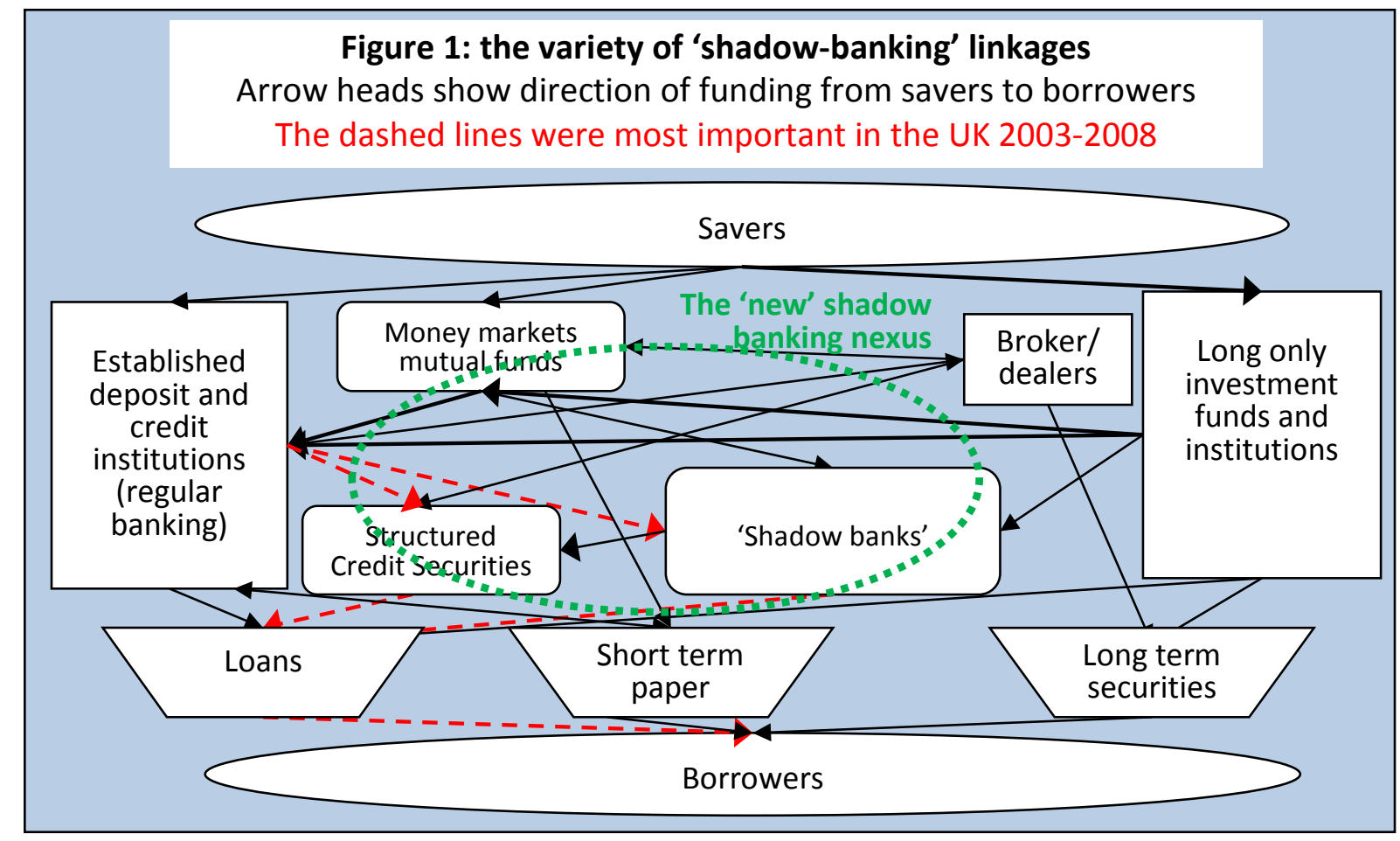

Some further interpretation of this figure can be offered:

- The shape labelled 'shadow' banks represents the very wide range of different institutions, operating outside of the regular banking system, that have been a source of systemic vulnerability in previous financial crises. Examples (there are many) include (i) the secondary banking crisis in the UK of 1973-74; (ii) centralised mortgage lenders that were most exposed to losses on UK mortgage lending during the downturn of 1992-93; (iii) the Thai finance houses that were the first casualties of the Asian financial crisis of 1997-98; (iv) the 'structured investment vehicles' (SIVs) that collapsed at the onset of the global financial crisis in 2007 and triggered substantial losses for German and other banks; and ( $v$ ) the private commercial real estate funds that have been a prominent source of recent UK bank credit losses following the crisis of 2007-2008.

- A further dimension, not fully captured in the figure, is the role of money market (short term) lending, both secured and unsecured. Money market intermediation is a major source of short term funding to commercial banks, leveraged credit funds and specialised lenders, and also to broker/dealers and (via direct investment in short term paper) private non-financial companies. Maturity mismatch using short term money-market instruments has contributed to many episodes of financial 
instability including those in Scandinavia, Japan and the UK in the early 1990s, the Asian crisis of 1997-98 (where Thai and South Korean institutions especially borrowed on a large scale in foreign currency in money markets, assuming that their currency peg meant that they were not exposed to exchange rate risk); and in the US in 2007-2008. ${ }^{6}$

- The shape labelled 'structured credit securities' represents the novel instruments (mostly issued in US dollars) that played a central role in the global financial crisis of 2007-2008. ${ }^{7}$ The most important of these were residential mortgage backed securities (RMBS), commercial mortgage backed securities (CMBS), credit card and other loan structures (usually referred to as ABS), syndicated loan structures (CLOs), structures build on credit derivatives (synthetic CDOs) and finally re-securitisations of credit structures (often referred to as ABS-CDOs). A key vulnerability of 2007-2008 was that the tranched instruments (in order of seniority: senior, mezzanine, junior and equity tranches) issued by these credit structures were held to a large extent in trading book by banks, by broker dealers and by leveraged credit funds and funded in money markets. ${ }^{8}$ Long-only investment funds and institutions made only very limited investments in these new dollar denominated credit instruments. ${ }^{9}$

While the 'shadow banking' linkages illustrated in Figure 1 have often been a source of financial instability, financial crises have often occurred without them. Over the years commercial banks have proved quite capable of getting into deep trouble, often needing government intervention to ensure their survival, without recourse to either novel financial instruments or off-balance sheet intermediation. Before the recent problems of UK banks such as HBOS or RBS, other examples include the Latin American debt crisis, the US Savings and Loans losses of the 1980 s and many banking failures in emerging markets since the

\footnotetext{
${ }^{6}$ Contrary to widespread perceptions the UK bank Northern Rock made only limited use of money market borrowing: its main sources of wholesale funding was through the issue of mortgage backed securities and covered bonds (see Milne and Wood (2008)). The reason that it got into liquidity problems was that it adopted a practice of lending first, using unsecured money market borrowing as a temporary source of funds, before later transferring repackaging loans into mortgage backed securities. When the markets for securitisation froze in 2007 it had no alternative source of funding available to it.

${ }^{7}$ See Milne (2009a) Table 3.2 for an analysis of the various components of this \$13trillion market.

${ }^{8}$ Milne (2009b) chapter 6 describes these trading book strategies, in particular the 'negative basis trade' and their role in the crisis of 2007-2008.

${ }^{9}$ See Milne (2009b) for further analysis and discussion.
} 
early 1970s. Such direct exposure has also been a feature of Euro area banking problems, with for example the recent large scale losses on property lending amongst both Irish and Spanish banks and the exposure of many banks to periphery Euro-area sovereign debt. These cases of financial instability have been associated with unsustainable credit expansion and with excessive maturity mismatch using short term wholesale money market funding, but undertaken directly by banks or other established deposit institutions, rather than through leveraged credit funds or specialised investors.

It should also be acknowledged that most episodes of financial instability, whether involving shadow banks or not, have been associated with excessive extension of credit secured on residential and commercial property and often, but not always, with unsustainable external borrowing. ${ }^{10}$ In a few other cases (Latin American exposures in the 1980 s or recent crisis in the periphery of the Euro area) banking problems have resulted from exposures to sovereign lending or sovereign debt. Occasionally, in some emerging markets with poor standards of governance, serious banking problems have been associated with large scale misuses of funds or other banking fraud.

\section{Shadow banking in the United States and offshore US dollar markets.}

In order to highlight the differences between 'new' and 'old' shadow banking, this subsection, and the one following, contrast the operation in recent years of shadow banking in US dollar markets with the shadow banking that developed in Europe and the UK.

According to Gorton (2010a) the ability to diversify their loan portfolios, and hence back bank deposits with comparatively safe if illiquid assets, made banks historically the natural suppliers of deposit money; but the new technologies of securitisation, secured lending (repo) and the hedging of associated default risk using credit derivative allowed non-bank intermediaries to displace traditional banks in the supply of seemingly riskless short-term liabilities backed by illiquid long term lending.

The most important of these liabilities was the sale or repurchase agreement (or repo), a form of secured borrowing. By agreeing to sell an asset and then subsequently repurchase

\footnotetext{
${ }^{10}$ Some references from an extensive literature include Goodhart and Delargy (1998); Kaminsky and Reinhart (1999); Davis and Zhu (2004); Reinhart and Rogoff (2009).
} 
at a slightly higher price, a borrower pays the equivalent of an interest rate; but risk is limited by the practice of requiring 'haircuts', i.e. the extent to which the actual market value of the asset (for example \$100) exceeds the agreed repurchase price (for example \$95). ${ }^{11}$ Another important form of secured borrowing used to finance securitised loans was 'asset backed commercial paper' or ABCP, a short term tradable paper secured on structured credit securities. $^{12}$

Adrian and Shin (2009) highlight the use of repo by US broker-dealers (investment banks) for the leveraged purchase of structured credit and other financial assets. Adrian and Shin (2010) document a strong positive relationship between changes in US broker-dealer leverage (largely through repo) and changes in balance sheet size.

The rapid growth in the issue of mortgage backed securities and other structured credit assets, financed using these various forms of short term borrowing, came to a sudden halt in mid-2007. A major reason was the lack of transparency regarding underlying asset quality: investors were acquiring shadow banking exposures with little regard to which assets were safe and which had more underlying risk; asymmetric information became an inherent problem. $^{13}$

As depositors panicked, the highly liquid market shrank drastically and liquidity vanished. Gorton and Metrick $(2010,2012)$ interpret the crisis of 2007-09 as a banking panic centred on the repo market and triggered by a loss of confidence in structured credit securities. This created feedback effect in which stronger balance sheets feed greater demand for the asset, which in turn raises the asset's price and lead to stronger balance sheets; while weakening balance sheets trigger the reverse mechanism, a mechanism that had been analysed even before the crisis by Brunnermeier and Pedersen (2008).

To illustrate this mechanism, ( Gorton and Metrick 2009) document the dramatic rise in haircuts across asset classes. Before the financial crisis, haircuts were close to zero for many asset classes, and only a little higher at around $5 \%$ when using on subprime mortgage

\footnotetext{
${ }^{11}$ In this case the haircut of $\$ 5(\$ 100-\$ 95)$ protects the repo lender from loss in the event of default, because even if the value of the asset should fall by $\$ 5$ they can still sell the asset and get back the money owed $(\$ 95)$.

${ }^{12}$ For description and discussion see (Pozsar et al. 2010)

${ }^{13}$ For elaboration see for example Ashcraft and Schuermann (2008) and Gorton (2009).
} 
backed securities and related assets as collateral. From July 2007 onwards the haircuts on subprime mortgage backed and related securities rose rapidly eventually climbing to $100 \%$; i.e. these assets were no longer acceptable as collateral in repo. Haircuts on non-subprimerelated asset classes also rose sharply to a maximum of $20 \%$.

A related mechanism that again contributed to the panic was that of rehypothecation, i.e. the practice of re-using collateral that had been obtained in return from extending repo finance in order to raise funds. In this way collateral could be passed on in a chain from one institution to another. Singh and Aitken (2009) show how the amount of rehypothecation has declined substantially since Lehman Brothers' bankruptcy due to the fear of losing collateral if the broker dealer becomes insolvent. Also, as documented by researchers at the Bank for International Settlements, much of the financing of US dollar structured credit securities was offshore, booked by institutions in Europe and elsewhere, and triggering a worldwide dollar shortage when the crisis broke (McGuire and Von Peter 2009; He and McCauley 2010).

What was the magnitude of US dollar shadow banking? The answer depends on what exactly is included as shadow banking. The volume of low-risk mortgage backed securities issued by the US government sponsored agencies Fannie Mae and Freddie Mac, meant that assets held outside of the US banking system surpassed those held by commercial banks as early as the mid-1990s. ${ }^{14}$ However this is not the 'shadow banking' that proved so unstable during the global crisis, because most of these agency securities were held by long term investors without maturity mismatch.

An alternative measure is to look at total repo borrowing. Gorton (2010b) estimates the US repo market to have been $\$ 12$ trillion in 2007 just before the crisis, compared with the total assets in the US banking system of \$10 trillion. Hördahl and King (2008) claim that the former top US investment banks funded roughly half of their assets using repo markets, with additional exposure due to off-balance sheet financing of their customers. The collateral often consisted of securitized loans and other structured credit instruments. Gorton and Metrick (2012) estimate that net repo financing provided to broker dealers fell

\footnotetext{
${ }^{14}$ For a detailed discussion see Pozsar, et al (2010).
} 
by $\$ 1.3$ trillion from the second quarter of 2007 to the first quarter of 2009 . The flight of capital was driven by money market funds, foreign financial institutions, domestic and offshore hedge funds, as well as other unregulated cash pools.

Other researchers reach even higher estimates of the size of US 'shadow' banking. Only biparty, not tri-party, agreements are captured by the Federal Reserve data (tri party is when repo assets are held with a third party institution a common arrangement in the US but not in Europe). Therefore, allowing for tri-party repo, even larger estimates of the magnitude of shadow banking can be obtained. Pozsar, et al (2010) estimate the US shadow banking sector to be $\$ 20$ trillion in March of 2008, falling to $\$ 16$ trillion in 2010. Pozsar and Singh (2011) estimate that the size was $\$ 25$ trillion in the US at the end of 2007 and $\$ 18$ trillion at the end of 2010.

All these repo based estimates, however, substantially overstate the total amount of shadow banking, because only a share of repo finance is used to support bank like credit intermediation. A better approach is to identify more directly the type of intermediation supported by different groups of institutions, an approach adopted by the Financial Stability Board and described in the next subsection. This approach suggests that US shadow banking (excluding the GSEs) was only around \$3trn at end 2012.

\section{Shadow banking in the Euro area and the United Kingdom}

Having described US dollar shadow banking, we now review available statistical information on shadow banking in Euro and sterling markets in the years before and after the global financial crisis. Our main conclusion is that, while there is considerable uncertainty about the amount of shadow banking intermediation, the overall amount of credit intermediation by shadow banks independent of the established banking system remains relatively small in other currencies than the US dollar. This is consistent with the fact that Euro and sterling securitization took place on a much smaller scale than in US dollars and these securities were to a much larger extent retained on bank balance sheets, for example to be used as collateral for borrowing from the Bank of England and the ECB. ${ }^{15}$

\footnotetext{
${ }^{15}$ For comparison of European and US securitisation before the crisis see Milne (2009a).
} 
The most comprehensive measures of shadow banking activities are those being developed by the Financial Stability Board, in their 'Global Shadow Banking Monitor' which aims to reveal detailed trends in shadow banking activity on a global and jurisdiction by jurisdiction basis. The most recent of these (Financial Stability Board 2013) includes relatively aggregated data for 20 jurisdictions plus also the Euro area. Total intermediation by 'other financial intermediaries' grew from \$66tn in 2011 to $\$ 71$ trn in 2013 . This represents about $24 \%$ of total financial sector assets, half of banking system assets and $117 \%$ of the GDP of the countries covered, a little below the 125\% of GDP in 2007.

This is measure is however far in excess of the actual level of shadow banking activity, since the measure include intermediation by all 'other financial intermediaries' and much of this intermediation is not shadow banking at all. It includes a number of intermediaries such as hedge funds, equity mutual funds, private equity funds, broker-dealers and others which do not intermediate credit or engage in maturity mismatch and are therefore not shadow banks. The intention of the FSB is that this statistical framework should be eventually refined to identify, separately shadow banks i.e. those 'other financial intermediaries' engaged in credit intermediation and exposed to bank like risks from leverage and maturity mismatch, but to date their statistics do not provide this level of disaggregation.

A further concern with the FSB measures, especially when looking at their reported figures for individual jurisdictions, is that they do not distinguish offshore intermediation between non-domestic investors and borrowers, from onshore intermediation. This boosts the magnitude of other financial intermediation relative to GDP in jurisdictions with substantial offshore activity such as the UK, Hong Kong and some parts of the Euro area. ${ }^{16}$

Financial Stability Board (2013) provide some supplementary breakdown of 'other financial intermediation' for 25 jurisdictions (the coverage of the Euro area is incomplete). This reveals (see especially Exhibit 4.2) that at end 2012 structured finance vehicles - which are central to the 'new' shadow banking documented by Gorton and Metrick (2010) and others amounted globally to around \$5trn at end 2012 (of which 35\% were booked in the US and

\footnotetext{
${ }^{16}$ A related concern applies to FSB figures for the Netherlands where some two thirds of 'other financial institutions' are some 14 thousand 'Special Financial Institutions' used by foreign owned multinationals to facilitate intergroup transactions and raise external funding. See Financial Stability Board (2013) footnote 30.
} 
$13 \%$ in the UK, but many outside the US were in fact holding US dollar assets); finance companies (in our terminology 'old' shadow banks) were also around \$5trn; money market mutual funds were about $\$ 4$ trillion; real estate investment trusts less than $\$ 1$ trn.

An alternative attempt to estimate the magnitude of shadow banking in the Euro area and the UK can be found in Bouveret (2011) (see Table 1, below). Bouveret estimates the size of the European shadow banking sector to be around \$13 trillion in the end of 2010 compared to $\$ 15.8$ trillion in the United States. While the sector has declined by $20 \%$ since the beginning of 2008 in the United States but did not decline in Europe, in part because European Central Bank took mortgage backed securities and other forms of structured credit instrument as collateral for its liquidity provision in the Eurozone. 
Table 1: Bouveret (2011) estimates of U.S. and European shadow banking (2010Q4, US\$\$bn)

$\begin{array}{lrr}\text { Component } & \text { U.S. } & \text { Europe } \\ \text { Total outstanding open market paper } & 1057 & 563 \\ \text { Total repo liabilities } & 1213 & 8086 \\ \text { Net securities loaned } & 733 & - \\ \text { Total shares outstanding of money market mutual funds } & 2755 & 1550 \\ \text { Total for maturity transformation } & \mathbf{5 7 5 8} & \mathbf{1 0 1 9 9} \\ \text { Total liabilities of ABS issuers (non-GSE structured credit) } & 2333 & 2860 \\ \text { Total GSE liabilities } & 6561 & - \\ \text { Pool securities } & 1166 & - \\ \text { Total for credit transformation } & \mathbf{1 0 0 6 0} & \mathbf{2 8 6 0} \\ \text { Total for the shadow banking sector } & \mathbf{1 5 8 1 8} & \mathbf{1 3 0 6 0} \\ \text { Commercial bank liabilities } & 12828 & 59640 * \\ \text { Traditional banks liabilities (a measure of deposits) } & 7791 & \mathbf{2 8 6 7 5} \\ \text { In \% of banks' liabilities } & \mathbf{1 2 3 \%} & \mathbf{2 2 \%} \\ \text { In \% of traditional banks' liabilities } & \mathbf{2 0 0 \%} & \mathbf{4 6 \%}\end{array}$

Notes on sources of data. MMFs info is taken from the industry (European Fund and Asset Management Association, EFAMA), central banks or commercial providers (Lipper). In 2010Q4 MMFs were measured as EUR 1182 billion (EFAMA), or EUR 1132 billion (ECB), or 1120 billion (Lipper). Commercial paper info is taken from the ECB and the STEP (Short Term European Paper) programme. In 2010Q4 CP was EUR 411.3 billion. Contrary to the US CP market, the European CP market did not experience a downturn during 2008Q4, and instead stabilized in early 2009. ABS info is taken from AFME (Association for Financial Markets in Europe). In 201004 ABS balances were EUR 2090 billion. September 2010, around EUR 500 billion of ABS were held on repo at the ECB according to AFME (2011), accounting for $24 \%$ of total collateral posted. Repo data is taken from the International Capital Market Association (ICMA). December 2010, value of repo contracts outstanding was EUR 5908 billion. While the European repo market declined during the crisis (by roughly $30 \%$ between 2008 Q 2 and 2008Q4), it has since increased. The US repo market declined by more than 50\% from 2008Q2 to $2010 Q 4$.

A more detailed examination of Bouveret's numbers, shown in Table 1, suggests that there are problems with the interpretation of these estimates, especially for Europe. First there is considerable double counting, arising from the inclusion of both shadow banking liabilities (money market mutual funds, repo) and shadow banking assets (structured credit securities) in the total estimate of aggregate shadow banking. Second, like researchers examining the size of the US shadow banking, Bouveret does not distinguish between the use of repo to finance holdings of structured credit instruments from their use to finance other positions including taking both long and short positions in government and corporate bonds. Bouveret adds repo and reverse repo and dividing by two to obtain an average figure; ${ }^{17}$ but a brief examination of the figures for repo finance in bank accounting statements suggests

\footnotetext{
${ }^{17}$ Reverse repo is simply the other side of a repo contract, so repo is used for collateralised borrowing of money by offering a security as collateral, while reverse repo is used to lend money while in return holding a security as collateral.
} 
that this could exaggerate the amount of net repo funding available to finance holdings of structured credit instruments by ten or more times. ${ }^{18}$

Third Bouveret does not take account of the very different institutional features of money market mutual funds in the US and Europe. Many MMFs in Europe, especially in France, are in fact bank sponsored and used for financing their parent bank (in France for example the 'Livre A' funds created largely to take advantage of tax concessions) and do not represent disintermediation. Fourth the Bouveret figures on 'ABS' (mortgage and other asset backed securities) do not distinguish the large amount of ABS created in Europe simply for the purpose of obtaining liquidity from the European Central Bank and the Bank of England.

Another comparison of repo activities, this time between the United States and the United Kingdom, is presented by Hördahl and King (2008). Since 2002, repo markets had doubled in size; $\$ 10$ trillion in each the US and euro repo markets and \$500 billion in the UK repo market at the end of 2007. As liquidity dried up, repos became increasingly concentrated in the shortest maturities and only against the highest-quality collateral. The Bank of England gathers data from roughly 60 banks and broker dealers for the UK repo market. Total repos and reverse repos reached a peak of $£ 662 \mathrm{bn}$ or around $50 \%$ of UK GDP in mid-2007 (this includes both sterling but more importantly foreign currency repo). Approximately four to six banks dominated the market with banks accounting for three quarters of transactions while securities houses, building societies, fund managers and insurance companies account for the remainder. Strikingly, in mid-2007 while the repo market in the US was under stress the euro area and UK markets operated under much calmer conditions.

To conclude: there are considerable statistical uncertainties about the magnitude of the shadow banking in the US, the Euro area and the UK. The more detailed breakdowns from the Financial Stability Board suggest that the core activities associated with shadow banking, in which bank like risks of maturity mismatch and leverage have often arisen - both the structured credit vehicles characteristic of what we call 'new' shadow banking and the finance companies and real estate investment trusts associated with what we describe as 'old' shadow banking - are together only \$11trn across 20 major jurisdictions including the

\footnotetext{
${ }^{18}$ We also note the inconsistency between the Bouveret measure of US repo markets which is an order of magnitude lower than that provided by other researchers. This may be due to his aggregation method.
} 
US, the UK, Germany, France and Italy. The repo based estimates that have been so widely quoted by economics researchers as suggesting that shadow banking has grown worldwide to as much as $\$ 30$ trillion or more (approaching 50\% of global GDP) are a therefore a substantial overstatement of the overall magnitude of shadow banking.

Moreover it remains unclear if anything like the 'new' shadow banking that emerged in the United States has financed domestic credit to any significant degree in the Euro area or the UK. We now turn to examine the case of the UK in much greater detail, showing that what happened in this case was 'old' rather than 'new' shadow banking based on bank lending and unsecured money market funding of non-bank specialized lenders, especially in the commercial property sector.

\section{Shadow banking and the UK credit expansion}

This section documents, using available data, the UK credit expansion of 1997-2008 and the role played by 'shadow banking', wholesale funding and securitisation to support the expansion of UK credit. It also compares this episode with the earlier property related credit losses of 1973-74 and 1991-93.

\section{UK credit expansion prior to the crisis}

All the data presented here are for sterling money and credit of UK monetary and financial institutions. ${ }^{19}$ Foreign currency lending and deposit takes place in the UK on a large scale but this is not part of the UK credit expansion since it is overwhelmingly off-shore banking in which both borrowers and depositors are non-residents.

Figure 2 shows the evolution of UK broad money (M4), as a percentage of GDP from 1982 to 2013. The substantial difference between the two upper lines in this figure highlights a challenge in understanding the data on the UK credit expansion of 2002-2007: there was a dramatic growth in both bank lending to and funding from what the Bank of England

\footnotetext{
${ }^{19}$ The data in Figures 2-7 are mostly taken from the Bank of England Statistical interactive database (http://www.bankofengland.co.uk/boeapps/iadb/). An online appendix details our use of this data.
} 
statistics describe as the 'Intermediate OFC (Other Financial Corporations)' sector. ${ }^{20}$ As described by the Bank of England these Intermediate OFCs consist of ' non-bank credit grantors (including securitisation vehicles); mortgage and housing credit corporations; bank holding companies; other activities auxiliary to financial intermediation; and other financial intermediaries, to the extent that these deposits are held with MFIs in the same group of financial companies (i.e. 'intra-group' deposits). ${ }^{21}$ For the purpose of analysing monetary conditions, for example in their Inflation Report, the Bank of England prefers to monitor M4 excluding deposits from these entities, on the ground that this narrow measure of money has a closer relation to nominal spending and is therefore economically more meaningful.

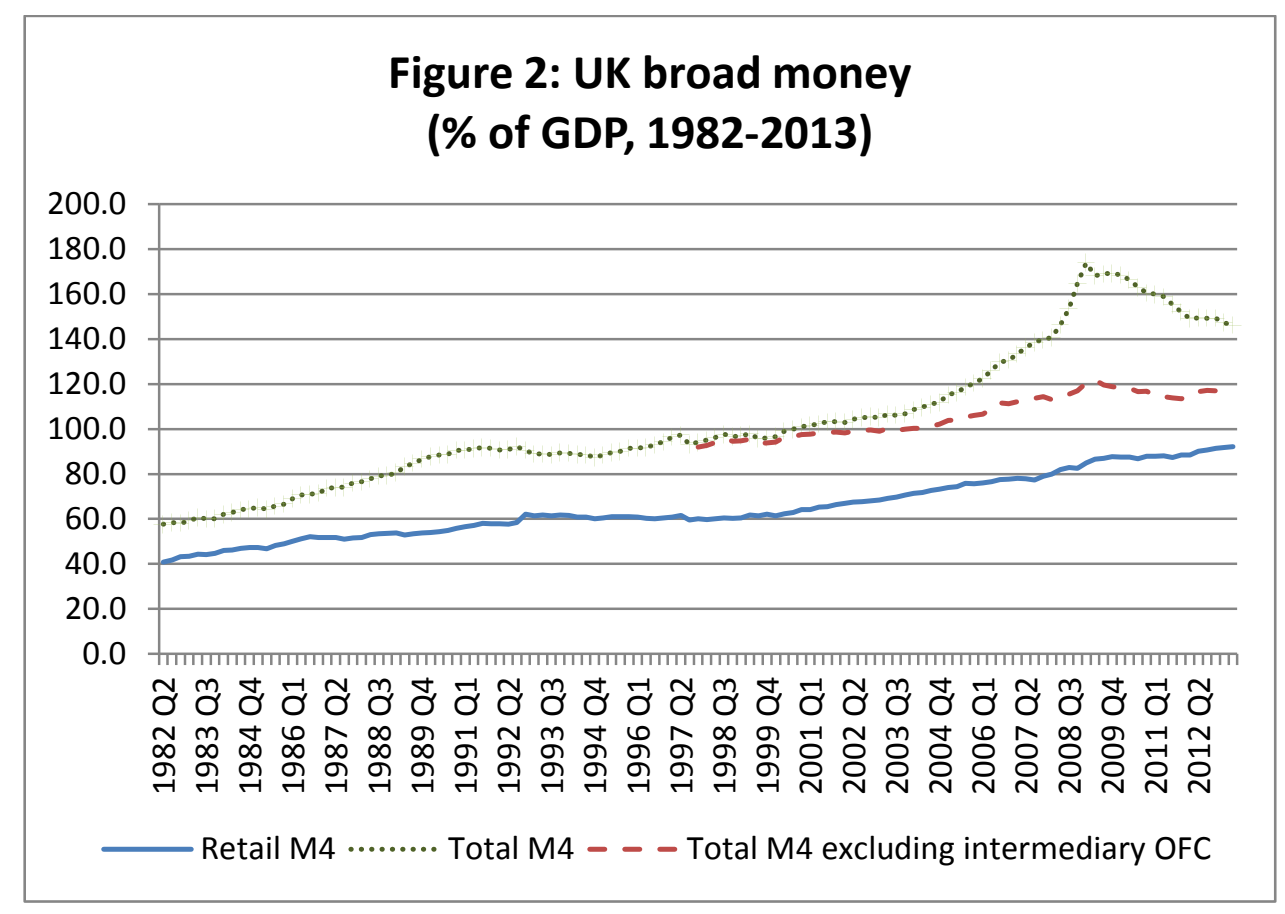

\footnotetext{
${ }^{20}$ Even larger levels of broad money result including deposits from other OFCs, such as life insurance and pension funds, central counterparties, or securities brokers; these are excluded entirely from Figure 2.

${ }^{21}$ For more detailed discussion see Janssen (2009). According to the Bank of England Statistical Interactive Database, Table $C$ further analysis of deposits and lending, the breakdown of intermediate OFI lending in Dec 2012 was as follows: loans to 'activities auxiliary to financial intermediation' (apparently fund management) $£ 121 \mathrm{bn}$, 'intra-group lending' $£ 150 \mathrm{bn}$, lending to securitisation special purpose vehicles $f 19 \mathrm{bn}$, loans to bank holding companies $£ 29 \mathrm{bn}$, loans to non-bank credit grantors $£ 13 \mathrm{bn}$, and loans to mortgage and housing credit corporations $f 55 \mathrm{bn}$, a total of $£ 387 \mathrm{bn}$. The corresponding sterling deposits and repos were: from securitisation special purpose vehicles $£ 212 \mathrm{bn}$, Intragroup deposits $£ 110 \mathrm{bn}$, from bank holding companies $£ 18 \mathrm{bn}$, from mortgage and housing credit corporations $£ 14 \mathrm{bn}$, from non-bank credit grantors $£ 2 \mathrm{bn}$, and finally from fund management companies f60bn.
} 
As Figure 2 indicates much of the notable growth in intermediate OFC deposits occurred post-crisis, their ratio to GDP increasing from 19 percent of GDP in $2008 \mathrm{Q} 2$ to 50 percent of GDP in 2010Q1, before falling back to 29 percent of GDP in 2013Q2. ${ }^{22}$ There is also a notable growth in intermediate OFC deposits in the period running up to the crisis, rising from around $2 \frac{1}{2}$ percent of GDP in 2003 to 19 percent of GDP in 2008. In the late 1990s the ratio was close to zero. Over the same period lending to intermediate OFCs grew even more rapidly (see the discussion of Figure 3 below).

Figure 2 indicates that during the run-up to the crisis wholesale funding of UK monetary institutions, excluding deposits from intermediate OFCs, grew at a similar rate to retail deposits in M4 (the two lower lines in the figure). However since lending was growing more rapidly than deposits (documented in Figures 3 and 4 below) other further sources of funding must have been used to support lending growth.

The relatively rapid growth of M4 lending to the non-financial private sector, relative to the stock of retail deposits, is shown in Figure $3 .^{23}$ This uses three measures of sterling lending available from the Bank of England statistics. The first and lowest in most years is lending on balance sheet (sometimes called M4L). The second (sometime called M4Lex) is described on the Bank of England website as 'M4 lending excluding the impact of securitisation', a rather confusing description since this measure rather than excluding securitisation actually adds back securitised lending which is not reported on balance sheet. This chart also reports the broadest measure of M4 lending, including that to intermediate OFCs. Since intermediate OFCs includes lending to securitisation vehicles and to housing and mortgage credit andhousing institutions this additional measure is the most comprehensive measure of

\footnotetext{
${ }^{22}$ This is largely accounted for by a substantial increase in deposits from securitisation special purpose vehicles/mortgage and housing credit corporations from March 2008 until Dec 2010 (during this period these two series are not reported separately although it is clear for later figures that most of these deposits are from special purpose vehicles). The Bank of England database provides no further detail but the most obvious interpretation is that this large increase from March 2008 resulted from the Bank of England lending large sums to securitisation vehicles via 'repo' of residential mortgage backed securities, with these funds in turn being deposited with sponsoring banks. These numbers may also be affected by changes in the reporting base or a changed accounting treatment of SPVs when they required support from their sponsoring banks.

${ }^{23}$ Apart from lending to intermediate OFCs this graph excludes all M4 lending to other financial corporations, described by the Bank of England as follows 'Other financial corporations (Items 15-17) are private financial corporations (other than monetary financial institutions) engaged primarily in provision of financial services. Examples include financial intermediation, insurance companies and pension funds and activities auxiliary to financial intermediation (e.g. fund management).' (http://www.bankofengland.co.uk/statistics/pages/iadb/notesiadb/industrial.aspx)
} 
lending; however it also includes a lot of lending which is redeposited with the monetary financial institution sector. In addition Figure 3 reports two narrower members of M4 lending, excluding intermediate OFCs and to h/holds and non-financial companies (NFCs).

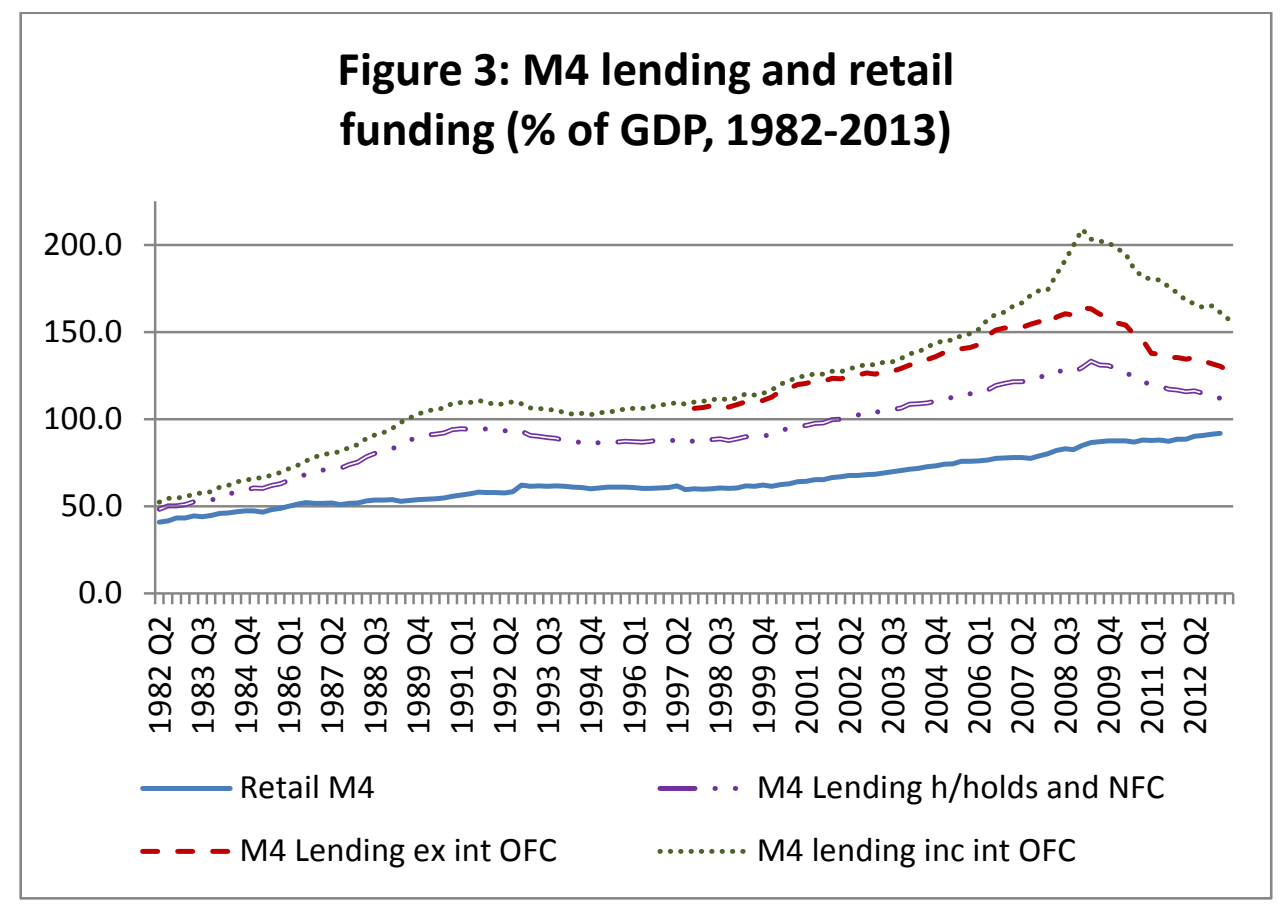

Figure 3 reveals a fairly stable relationship between on-balance sheet sterling lending to households and non-financial companies and retail deposits, with total 'conventional' lending of this kind exceeding retail deposits by around 40\% of GDP from the early 1990s to the late 200s. In contrast other forms of lending to other (non-bank) financial institutions frew rapidly throughout this period (and as indicated by Figure 2 accomapnied by substantial growth in bank deposits from non-bank financial institutions).

There is though evidence of lending outstripping deposits in Figure 4, constructed using Bank of England statistics for household lending and deposit taking. As indicated in this figure household lending grew much faster than household deposits, from the late 1990s to 2008 , all of which can be accounted for by an increase in the ratio of mortgage lending to GDP from 52 percent of GDP in mid-1999 to 86 percent of GDP in the first half of 2009. Over the same period the gap between household deposits and total household lending grew from 7 percent of GDP to 23 per cent of GDP. It has since fallen back to around the 1997 level as UK households have rebuilt their balance sheets. 


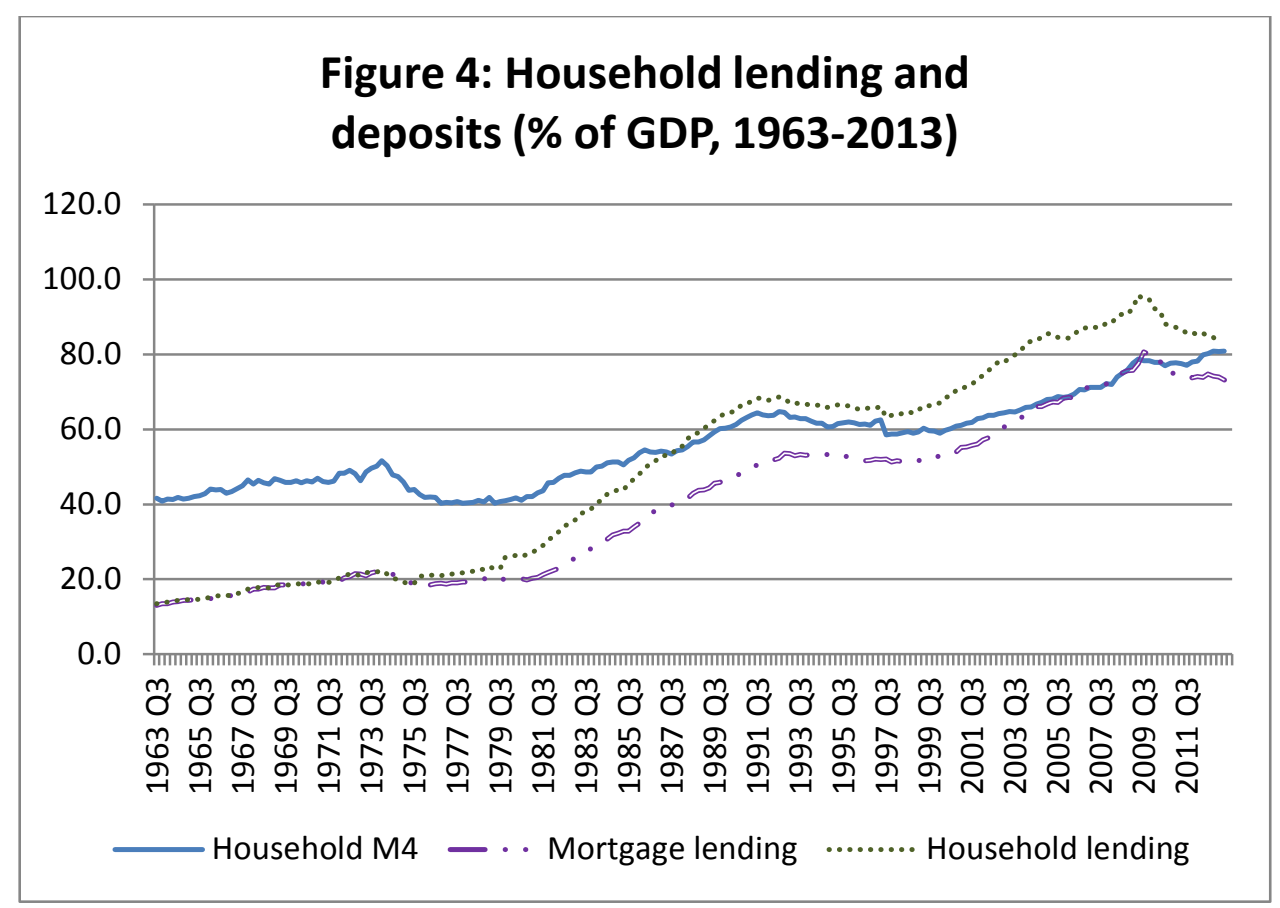

M4 lending only includes lending to the non-financial corporate sector monetary financial intermediaries. A recent Bank of England analysis by Benford and Burrows (2013a) provides a fuller picture of one major corporate lending market, that for commercial real estate (CRE). They report that $£ 247 \mathrm{bn}$ of the outstanding debt secured on CRE at end-2010 was bank lending, with about two-thirds of this lending provided by UK-owned banks and the rest by foreign owned banks. This amounts to about two thirds of all UK resident bank lending to non-financial corporations.

Compiling data from a variety of sources, they report that total debt secured on commercial real estate rose rapidly in the year preceding the crisis, growing from around $f 110 \mathrm{bn}$ at end2002 to around $£ 300$ bn at end-2008 (Source Benford and Burrows (2013a) , page 55, Chart A) . This represented an increase from $11 \%$ of nominal GDP in 2002 to $23 \%$ of GDP in 2008 , and accounts for close to one-third of the increase in the ratio of M4 lending to GDP over the same time period shown in Figure 2.

The CRE lending documented by Benford and Burrows (2013a) can be roughly matched to the industrial and sectoral allocation of M4 lending to the non-financial corporate sector in the Bank of England statistical database. Table 2 uses this data to present a breakdown of total M4 lending into various property related and other components as a per cent of GDP. 
Table 2: property related lending components of M4 (\% of GDP)

$\begin{array}{rrrrrr}\begin{array}{r}\text { Construction } \\ \text { companies }\end{array} & \begin{array}{r}\text { Real estate } \\ \text { agents and } \\ \text { funds }\end{array} & \begin{array}{r}\text { Mortgage } \\ \text { and housing } \\ \text { corporations }\end{array} & \begin{array}{r}\text { Residential } \\ \text { mortgage } \\ \text { lending }\end{array} & \begin{array}{r}\text { Non- } \\ \text { Total property } \\ \text { related lending }\end{array} & \begin{array}{r}\text { Property } \\ \text { related M4 } \\ \text { lending }\end{array} \\ (1) & (2) & (3) & (4) & =(1)+(2)+(3)+(4) & (6) \\ 0.9 & 4.3 & 1.3 & 51.9 & 58.4 & 29.3 \\ 0.9 & 4.7 & 1.3 & 51.8 & 58.7 & 29.4 \\ 0.9 & 5.1 & 1.9 & 53.1 & 61.1 & 29.6 \\ 1.2 & 6.3 & 1.7 & 55.9 & 65.2 & 31.7 \\ 1.4 & 7.6 & 1.9 & 58.2 & 69.1 & 32.1 \\ 1.5 & 8.7 & 2.5 & 62.2 & 74.8 & 31.7 \\ 1.4 & 9.4 & 3.2 & 65.9 & 79.9 & 29.4 \\ 1.5 & 10.4 & 4.7 & 69.3 & 86.0 & 27.9 \\ 1.6 & 11.7 & 5.0 & 71.8 & 90.0 & 29.2 \\ 1.6 & 13.1 & 6.1 & 75.7 & 96.5 & 29.9 \\ 2.0 & 14.8 & 6.4 & 78.6 & 101.8 & 30.3 \\ 2.4 & 18.6 & 12.6 & 83.3 & 116.9 & 20.9 \\ 2.0 & 18.8 & 6.3 & 85.7 & 112.8 & 25.9 \\ 1.7 & 16.6 & 5.3 & 75.1 & 98.7 & 22.6 \\ 1.6 & 13.4 & 4.3 & 74.1 & 93.4 & 23.4 \\ 1.5 & 12.1 & 3.7 & 74.0 & 91.3 & 22.5\end{array}$

Source: Bank of England Interactive Statistical Database and authors' calculations. There is a break in the series for mortgage and housing corporations in 2010 when lending to securitisation vehicles is excluded.

Much of this lending is captured by the data base series RPQTBUT 'Sterling lending to firms involved in undertaking the buying, selling and renting of real estate' (column (2) of Table 2), a component of lending to the non-financial corporate sector. This lending to GDP grows from $2 \frac{1}{2}$ percent of GDP in 1986 to over 7 per cent in 1991, the peak of the ThatcherLawson credit boom. After declining to 4 per cent of GDP in 1997 it then rises strongly again reaching a peak of 19 per cent of GDP in 2009. Subsequently it has fallen back to 12 percent of GDP in 2012.

A further part of property related lending is recorded by the Bank of England as part of lending of Other Financial Corporations (OFC) as series RPQTBVN "Sterling lending to mortgage and housing corporations" (column (3) of Table 2). Until Dec 2010 this series also includes lending to special purpose securitisation vehicles. This lending series rises from 1 percent of GDP in 1997 to 61/2 per cent of GDP in mid 2007 (and rises further to 12 per cent of GDP in 2009, we believe this is because many banks were forced to lend money to fund their own securitisation vehicles). 
The sum of these two property related lending series rose from 5 per cent of GDP in 1997 to around 25 percent of GDP at the beginning of the crisis. Over the same period residential mortgage lending rose from 52 percent to 85 percent of UK GDP. Taken together with a much smaller rise in lending to property construction companies (column (1) of Table 2) from about 1 percent to 2 percent of GDP, property related lending accounts for all of the increase in sterling M4 lending relative to GDP during the credit expansion of 1997-2007. Non-property related lending (column (6) of Table 2 ) actually fell slightly over the same period. This was an old fashioned property lending boom.

Figure 5 shows the impact of this property lending boom on the composition of total M4 lending (including securitised loans, excluding lending to intermediate OFCs but adding back lending to mortgage and housing credit corporations) to the personal, non-personal household and corporate sectors. This share of mortgages in total lending actually falls slightly during the years 1997-2008, due to the even more rapid growth of lending secured on commercial real estate. The share of personal non-mortgage lending and lending to the rest of the household sector (this includes lending to unincorporated businesses) declines.

The share of M4 lending going to real estate and construction companies of all types, including the listed and unlisted CRE funds analysed by Benford and Burrows (2013a) is represented by the gap between the green and upper blue lines of Figure 5. While this lending expanded extremely rapidly over the period 1997-2008, over the same period other forms of lending to non-financial companies falls from over 20 to less than 15 per cent of total M4 lending (although the total amount of this other lending did not change much as a share of GDP). 


\section{Figure 5: Composition of M4 lending ex int OFC (percent of total, 1984-2013)}

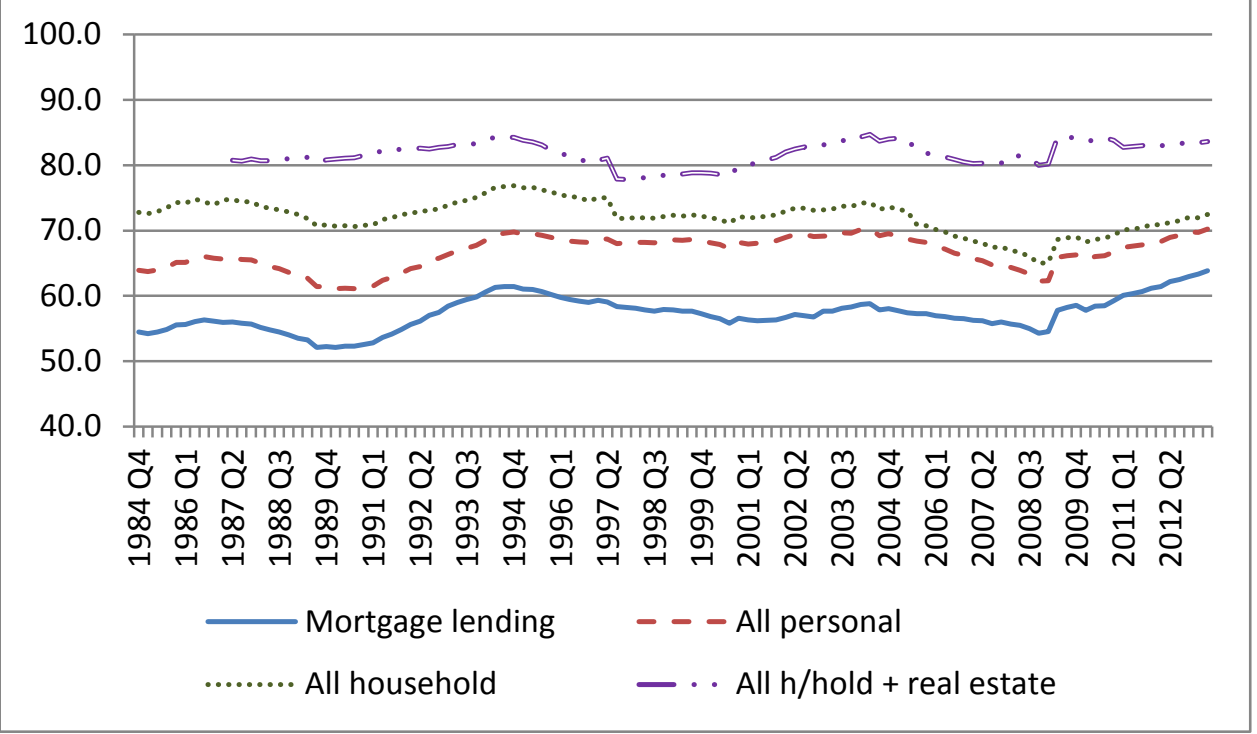

While the credit boom of 1997-2008 was dominated by lending on residential and commercial property, the risks exposures that resulted from this lending varied considerably from one category of loan to another; and also, depending on the quality of their loan books, from one lender to another. Table 3 shows five year cumulative loan write offs, for major categories of lending, again taken from Bank of England Statistics.

Table 3: Cumulative five year write-offs

\begin{tabular}{|c|c|c|c|c|c|c|c|}
\hline \multirow{2}{*}{\multicolumn{2}{|c|}{$\begin{array}{l}\text { All monetary institutions } \\
\text { UK sterling lending }\end{array}$}} & \multicolumn{3}{|c|}{ 2003Q3-2008Q2 } & \multicolumn{3}{|c|}{ 2008Q3-2013Q2 } \\
\hline & & fbn & Share & $\begin{array}{r}\text { Annual } \\
\text { Rate }\end{array}$ & $£ b n$ & Share & $\begin{array}{r}\text { Annual } \\
\text { Rate }\end{array}$ \\
\hline Non-financial corporations & (1) & 6.5 & $18 \%$ & $0.4 \%$ & 30.3 & $42 \%$ & $1.3 \%$ \\
\hline Other financial corporations & (2) & 0.3 & $1 \%$ & $0.4 \%$ & 2.2 & $3 \%$ & $2.5 \%$ \\
\hline Residential mortgages & (3) & 0.5 & $1 \%$ & $0.0 \%$ & 3.4 & $5 \%$ & $0.1 \%$ \\
\hline Credit card lending & (4) & 12.1 & $33 \%$ & \multirow{2}{*}{$3.7 \%$} & 17.5 & $24 \%$ & \multirow{2}{*}{$5.0 \%$} \\
\hline Other unsecured personal & (5) & 15.7 & $43 \%$ & & 15.1 & $21 \%$ & \\
\hline All lending to individuals & (6) & 28.3 & $78 \%$ & $0.6 \%$ & 35.9 & $50 \%$ & $0.6 \%$ \\
\hline Unincorporated businesses & (7) & 0.9 & $2 \%$ & $0.4 \%$ & 1.4 & $2 \%$ & $0.6 \%$ \\
\hline Non-residents & (8) & 0.5 & $1 \%$ & $0.1 \%$ & 2.0 & $3 \%$ & $0.5 \%$ \\
\hline Total & (9) & 36.5 & $100 \%$ & $0.2 \%$ & 71.8 & $100 \%$ & $0.4 \%$ \\
\hline
\end{tabular}

Source: Bank of England Interactive Statistical Database and authors' calculations.

Table 3 reveals that a total of $£ 71.8 \mathrm{bn}$ of UK lending has been written off since the second quarter of 2008 , representing $2 \%$ of the average stock of loans over the period 2008Q22013Q2. Of these the major contributions have been from credit card lending ( $f 17.5 \mathrm{bn}, 24 \%$ 
of the total), other unsecured personal lending ( $f 15.1 \mathrm{bn}, 21 \%$ of the total) and lending on commercial real estate (although not shown in this table these write-offs amounted to approximately $£ 20 \mathrm{bn}$, or $28 \%$ of the total). ${ }^{24}$ These three forms of lending together account for very close to three-quarters of all of these UK sterling loan write-offs.

Despite the very large increase in the ratio of residential mortgage lending to GDP, writeoffs on residential mortgage loans to individuals accounted were only $f 3.4 \mathrm{bn}, 5 \%$ of the total write-offs and less than $1 / 2$ percent of the 2008 stock of residential mortgages. Similarly low write off rates were recorded for lending to other financial corporations and to nonresidents. Finally about $£ 10$ bn of write-offs, $14 \%$ of the total, are against non-financial corporations not involved in commercial real estate.

Although credit card lending and unsecured personal lending both made a substantial contribution to total write-offs on sterling lending, the increase in UK sterling loan write-offs in this period (compared to the previous five years) is mostly from lending to non-financial corporations (and most of this was on commercial real estate lending). Comparing the first and fourth columns of Table 3 this category of write-offs accounts for $f 24 \mathrm{bn}$ of a total f35bn increase in write-offs, between 2003-2008 and 2008-2013. Write-offs on credit cards rose by only just over $£ 5 b n$, on mortgage by just under $£ 3 b n$, while write-offs on other unsecured personal lending actually fell from $f 15.7$ to $f 15.0 \mathrm{bn}$.

The high level of write-offs on credit cards and other unsecured personal lending reflects the fact that these categories of loans are always risky, regardless of the state of the wider macroeconomy. This is not such a problem to banks because the high levels of write-offs are anticipated and therefore interest rates on these forms of lending are set at sufficiently high levels to cover anticipated losses. The large increase in write-offs on loans to commercial real estate was a much bigger problem for UK banks because it was not anticipated; and therefore interest rates on this secured and therefore supposedly safe lending were far too low to absorb the losses.

\footnotetext{
${ }^{24}$ The breakout of write-offs for CRE lending is not available in the BoE database, and hence not distinguished in this table, but it is reported by Benford and Burrows (2013a).
} 
These write-offs of domestic sterling exposures were not the only source of losses, to UK owned banks and to other banks operating in the UK. Other major losses arose from (a) trading losses, including especially losses on investments in US dollar structured credit securities; (b) losses on lending outside of the UK, principally those of HSBC on its North American subsidiary HFC; (c) the large write-down of the Royal Bank of Scotland share of the acquisition of ABN-AMRO bank. Table 4 compares some measures of these further losses with those shown in Table $3 .^{25}$

Table 4: comparison of sterling credit write-offs with other losses

\begin{tabular}{|l|r|}
\hline fbn & \\
\hline UK sterling credit write-offs (from Table 3) & 71.8 \\
\hline Royal Bank of Scotland: 2008 write down of goodwill and other intangible assets & 32.6 \\
\hline $\begin{array}{l}\text { Losses on London investment banking operations (UK and International Banks, } \\
\text { January 2007 - March 2009) }\end{array}$ & 150 \\
\hline HSBC credit provisions for North American operations 2006-2010 & 28.8 \\
\hline
\end{tabular}

Sources: Table 3 plus RBS (2009); FSA (2010), HSBC 10-K reports to the SEC, and authors' calculations

Note that these losses on London investment banking are to a large extent accounted for by the activities of North American, Swiss, German and other international investment banks in London. The UK banks with substantial investment banking operations (HSBC, Barclays and Royal Bank of Scotland) account for a relatively small proportion of these losses (the FSA report from which this figure is taken does not distinguish the losses of these three UK owned investment banking subsidiaries from those of others). On the other hand the table excludes the losses of investment banking subsidiaries of these three banks outside of the UK. What Table 3 does show is that these UK sterling credit write-offs in Table 1 account for major share of the losses of UK banking sector.

The sterling credit exposure and experience of loan losses by banks and building societies in the UK, in the build-up to and materialisation of the financial crisis of 2007-2009, were similar in many ways to those experienced in the earlier major credit loss episodes in the UK of 1973-1975 and 1991-1993. As in the earlier crises there was a rapid growth of property

\footnotetext{
${ }^{25}$ Note that Table 4 arguably overstates investment banking trading losses, because it does not allow for recovery in market values since March 2009, and may not capture all UK bank loan losses since some further write-offs could possibly take place after 2013 (though with a recovering economy there could equally well be write-backs).
} 
related lending, through both residential mortgage lending and lending secured on commercial real estate.

One difference from 1991-93 is that this most recent growth in mortgage lending was followed by relatively modest write-offs of mortgage loans. The most obvious explanation for this is that in 1990-91 short term interest rates were maintained at very high levels in an effort to keep sterling within the European exchange rate mechanism. In the most recent period, in sharp contrast, short term interest rates were reduced sharply. This however did not prevent substantial write-offs on unsecured personal lending and on commercial property lending.

To what extent was this related to shadow banking? Figure 6 and 7 reports some indicators of UK shadow banking activity. The most salient feature of these charts is the substantial growth in issue of residential mortgage backed securities (RMBS) in Figure 6, from less than 2 per cent of GDP in 1999 to nearly 27 per cent of GDP at the start of the crisis in 2007 i.e. an increase of 25 per cent of GDP matching the increase in residential mortgage lending (Figure 4) over the same period from 52 to 77 per cent of GDP. ${ }^{26}$

Regrettably there are no statistics on the holding of these sterling residential mortgage backed securities: some tranches will have been placed in conduits used by the issuing banks to raise funding; other tranches will have been sold to long term investors; yet other tranches will have been purchased as trading assets by other banks or by hedge funds. Still, regardless of who was purchasing the securitisations, most risk will have been retained by the issuing banks. This is because even before the crisis only low risk mezzanine and senior tranches of RMBS could be readily sold. ${ }^{27}$

The AFME statistics used for Figure 6 also provide a breakdown of different types of securitisation in the UK (but without distinguishing sterling from foreign currency). These figures indicate that total outstanding securitisation in the UK in 2007Q2, was equivalent to $49 \%$ of GDP (about one fifth higher than the Sterling securitisation shown in Figure 6), with

\footnotetext{
${ }^{26}$ Bank of England data for securitisation in Figure 6 is available only back to 2010Q1, but this matches fairly well with the other series reported in Figure 6, AFME data for sterling securitisation that goes back to 1999. ${ }^{27}$ Milne (2009) chapters 4-6 discusses the role of securitisation in the global financial crisis in detail. There was no equivalent in sterling markets of the "ABS-CDOs" used to resecuritise unsold junior tranches of US\$ RMBS.
} 
securitised residential mortgage backed securities amounting to $31 \%$ of GDP, securitised commercial mortgage backed securities $8 \%$ of GDP and all other securitisations (credit cards, business loans and "collateralised debt obligations or CDOs") adding up to $10 \%$ of GDP i.e. residential mortgage backed securitisation was much more important than any other form of securitisation in the UK. Finally Figure 6 shows sterling repo financing by monetary financial institutions. This is much smaller than securitisation, but the series are not really comparable. $^{28}$

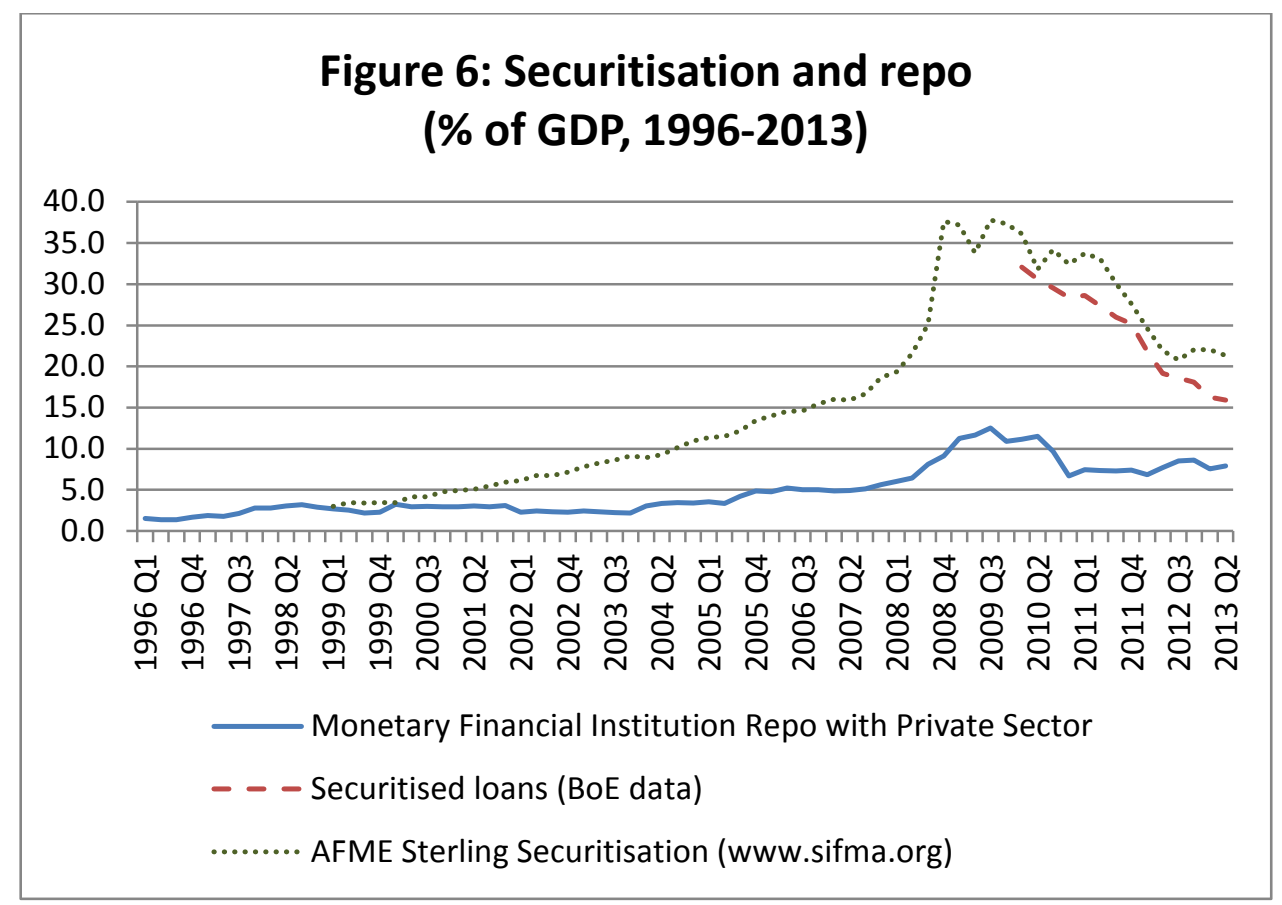

Source: Bank of England Interactive Statistical Data Base; Association of European Financial Markets (AFME)

Figure 7 shows two indicators of property related lending (other than residential mortgages provided to individuals), both taken from Table 2 above. These are Bank of England data on loans to real estate agents and funds (a component of lending to non-financial corporations) and lending to housing and mortgage credit corporations (a component of lending to intermediate other financial corporations). The definitions of these two series are both rather broad. Included in "housing and mortgage credit corporations", before 2010, are special purpose vehicles used for the issue of RMBS and the conduits used for holding and

\footnotetext{
${ }^{28}$ There will be other repo by financial institutions which are not classified as monetary financial institutions. The ICMA/ University of Reading for June 2007 indicates that total sterling repo in 2007Q2 amounted to f280bn, about four and a half times the level shown in Figure 6. At the same time, as discussed in Section 2, a much of this repo will be used for financing trading positions, not for holding structured credit securities such as RMBS.
} 
financing RMBS. With the onset of the crisis, from 2007Q2 onwards, as these off balance sheet vehicles were unable to obtain short term funding in the markets, banks were forced to lend to the vehicles they sponsored, increasing lending to Housing and Mortgage Corporations shown in Figure 6 substantially from 5\% to 13\% of GDP. This need to lend then declined as the Bank of England provided substantial repo finance secured against RMBS and CMBS.

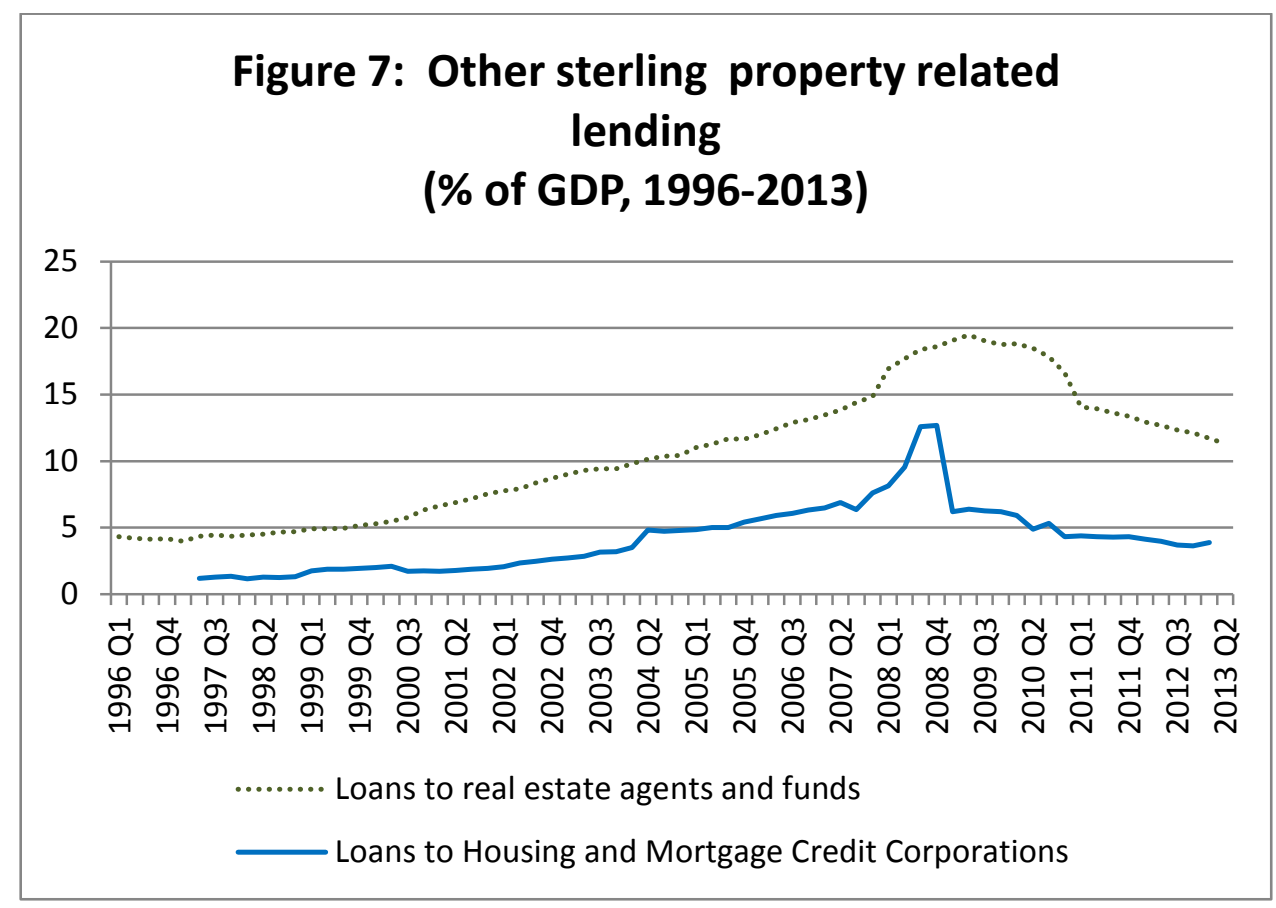

Source: Bank of England Interactive Statistical Database and author's calculations. Real estate agents and funds is an umbrella term including both agencies that provide services for the purchase of and sale of residential and commercial real estate and property companies that invest in real estate. Housing and Mortgage Credit Corporations includes a range of non-bank entities that hold assets secured on residential housing, including until 2009Q4 special purpose vehicles (SPV) used for securitisation of residential mortgages.

As described by (Benford and Burrows 2013) a large part of UK bank lending secured on commercial property was to property companies (with much of the rest to wealthy individuals). This property company lending is included in the second series in Figure 7 loans to real estate agents and funds. The large expansion of commercial real estate lending is a major reason for the increase in this category of lending from around $5 \%$ of GDP in the late 1990s to nearly $15 \%$ of GDP in 2007.

Two main conclusions can be drawn from Figures 6 and 7. While Bank of England statistics are not particularly informative about financial activities outside of the banking sector, there is little evidence to be found of 'new' shadow banking in sterling markets of the form that 
developed in the US, in the years preceding the global crisis. The securitisation of mortgages and other sterling lending was conducted by established banks, not by competing shadow banks, and used as a tool to secure further funding to continue the credit expansion. While banks were using off balance sheet vehicles to raise short term funding using securitised loans as collateral, the amount of 'emergency' lending to these vehicles suggested by Figure 7 , was only about $5 \%$ of GDP, indicates that the size of these off balance sheet vehicles was much less than total sterling securitisation.

The second conclusion -is that the main exposure that led to the large increase in sterling loan write-offs (shown in Table 3) was a substantial increase in rather conventional lending to property companies. Some form of 'shadow' banking may have played a secondary role in this boom and subsequent bust, but this was through REITs and other leveraged investment funds investing in commercial property (see Benford and Burrows (2013) for more detailed discussion of the activities of these other investors in commercial property).

\section{Comparison with the UK banking losses of 1973-74 and 1991-} 1993

This section briefly compares the most recent episode of bank credit losses in the UK with earlier episodes of 1973-74 and 1991-1993.

The 1973-74 shadow banking crisis has been documented in some detail by Reid (1982). While sterling foreign exchange controls continued to be applied until 1979, a gradual deregulation of domestic UK banking occurred from the late 1950s until the early 1970s. The relaxation of strict controls of lending for the purchase of consumer durables ("hire purchase") led to the creation of a number of finance groups seeking to provide loans to consumers and smaller businesses, but they had no banking license and their legal status as banks was unclear. As recognised in a famous judgement ((United Dominions Trust Ltd v. Kirkwood BT - QB 1966)) by Lord Denning, Master of the Rolls, these finance houses had a claim, under UK common law, to be regarded as banks simply by virtue of having practiced a lending business with rights to reclaim debts, and having been accepted as such by the investors and financial intermediaries that funded them. 
This somewhat unsatisfactory situation was addressed by Section 123 of the 1967

Companies Act, allowing the Board of Trade to issue certificates for organisations to engage in banking, alongside the already established banks, either those recognised under Schedule VIII of the 1948 Companies act or subsequently under Section 127 of the 1967 Companies Act (these were the most prestigious banks and included all the major high street 'clearing banks' as well as the 'discount houses' and 'merchant banks' in the City of London) or a number of other banks authorised by the Bank of England for participation in the London markets and largely engaged in foreign exchange business.

A large number of institutions took up the opportunity to obtain Section 123 banking certification, engaging in a wide range of credit provision especially property finance lending to housebuilders and to commercial real estate developers, not just consumer lending. By the autumn of 1973, just before the secondary crisis broke, there were 133 banks certificated by the Board of Trade and a further 323 banks recognised or licensed by the Bank of England (the so called "listed banks" because they were listed as contributors to the Bank's banking statistics). Amongst these listed banks Reid (1982) page 52, identifies some 34 banks that were engaged in similar business activities (property and consumer finance) to the new certificated banks, and can thus also be regarded as part of the secondary banking sector.

There was no clear responsibility for regulatory oversight. The Bank of England was primarily concerned with maintaining contacts with the clearing banks and discount houses with which it conducted its own market business. The City banks were regarded as self-policing because they engaged only in wholesale business. This freedom was reinforced, in 1971, by the introduction of the new monetary regime of 'Competition and Credit Control'. The direct controls on lending of the larger banks that had been a major instrument of monetary policy for two or more decades were scrapped; the clearing and other banks were encouraged to compete fiercely for business; and the primary monetary instrument became Bank of England control over short term interest rates.

The final say on the setting of interest rates remained however that of HM Treasury and their political masters. This political constraint on the raising of interest rates, combined with an expansionary fiscal stance of the new Conservative chancellor Anthony Barber ("the 
dash for growth") laid the foundations for a rapid boom property prices, for which the newly liberalised banking system was only to ready to provide the necessary credit. Reckless expansion was encouraged by extremely lax controls over lending risks amongst both established and secondary banks.

Reid (1982) pages 61-63 records that between October 1971 and December 1973 total sterling (listed) bank advances to domestic residents rose 148 per cent (from $14 \%$ to $27 \%$ of nominal GDP, modest proportions by the standards of later years, but a rapid rise nonetheless). These figures contain relatively little lending secured on residential property, because at that time banks were still not allowed to compete with building societies in the provision of long term residential mortgages.

This figure also understates the total creation of credit, because the 'unlisted' Section 123 banks appear in these statistics as borrowers rather than as lenders (the property and financial sector accounted for some $f 6.7 \mathrm{bn}$ of total bank lending in Dec 1973). Many of these unlisted Section 123 banks were able to extend much greater credit than they obtained from the 'listed' banks by borrowing on the rapidly expanding London wholesale money markets. Between October 1971 and December 1973 total money market deposits (unsecured interbank lending and sterling wholesale certificates of deposit) rose from $8 \%$ to $18 \%$ of GDP, with much of this money on lent by Section 123 banks. While there are no comprehensive figures, the situation of various individual institutions documented by Reid (1982) suggests that many of the secondary banks - which took very little in the way of retail deposits -- often raised half or more of their funding from wholesale markets.

While the property boom itself slowed in mid-1973, the crisis itself was not triggered until December of that year, when (in the context of gloomy economic environment with deteriorating industrial relations in the UK and the current threat of substantial oil price increases by OPEC) liquidity problems emerged at Cedar Holdings, one of the most prominent of the secondary banks. In an emergency overnight meeting $19^{\text {th }}-20^{\text {th }}$ December, the Bank of England persuaded major shareholders and Barclays bank to provided $f 72 \mathrm{mn}$ of funding to refinance the wholesale money market borrowing of Cedar. But the announcement of this rescue only triggered rumours of problems at other secondary banks. By Friday Dec $21^{\text {st }}$ the major clearing banks and the Bank of England agreed and announced 
the 'lifeboat operation' through which the major clearing banks would 'recycle' funds to replace wholesale deposit withdrawals from the secondary banking sector.

Eventually, by mid-1975, the lifeboat loaned out some $f 1.2 \mathrm{bn}$ (around $2 / 5$ ths of the equity capital of the clearing banks that backed the lifeboat) to 25 secondary banks (with $f 500 \mathrm{mn}$ provided to United Dominions Trust, the largest of the secondary banks that had 'listed' status). This lending, while gradually wound down after its 1975 peak, remained on the books of the clearing banks for several years. Of the 25 beneficiaries of the lifeboat, most disappeared, either through liquidation or through absorption into larger financial groups, and the remainder substantially contracted. Other secondary banks, strong enough to avoid the need to take lifeboat funds, similarly either exited from banking or were absorbed into larger financial groups.

It is not possible, even from the detailed research of Reid (1982) to compare the total property related losses that emerged following the 1971-1973 property boom with the commercial property losses experienced in the period 2009-2013. Much of the losses were at secondary banks outside of the compass of Bank of England banking statistics. If anything the scale of problems in the property sector seem to have been more severe than in 20032007 (see Reid (1982) chapter 8 for discussion of property loan difficulties); but the rapid inflation of 1974-1975, following the OPEC oil price shock, transferred resources from bank depositors to bank creditors, easing the burden of repayment and limiting loan losses.

The 1991-93 UK banking problems remain relatively poorly documented, compared to either $1973-75$ or 2007-2013. There is no comprehensive reviews of this crisis, of comparable detail to that provided by Reid (1982) for the secondary banking failures of 1973-75. Still information about the problems of these years can be obtained from subsequent Bank of England research (Jackson (1996); Logan (2000); Hoggarth and Soussa (2001)).

The banking sector problems of 1991-93, like the earlier episodes of 1973-75 and 2007-2012, were driven by a property lending cycle in which smaller 'shadow' banks participated. In 1991 there were 116 small banks in the UK, a large proportion of which engaging in lending secured on residential and commercial property lending; of these by 199325 had failed. But these shadow banks (in our terminology 'old' shadow banks because while much less closely 
regulated than the established banks they were not competing for deposit like liabilities) accounted for a very much smaller share of total credit provision than the secondary banks in 1973. Logan (2000) reports the total assets of the 92 small banks for which he was able to assemble data amounted to only $£ 15 \mathrm{bn}(2.6 \%$ of $1991 \mathrm{GDP})$ compared to the total assets of Barclays, the largest UK banking group at the time, which had total assets of $f 138 \mathrm{bn}(23.2 \%$ of GDP).

As documented by Vander Weyer (2000), Barclays was by some margin the most important lender in commercial property markets (for example Barclays was the principal creditor in the bankruptcy of Olympia and York, the property developers who built the Canary Wharf tower). Active participants in UK commercial property market lending also included a number of foreign banks. Shadow banks played a relatively small role in the property lending problems of 1991-1993.

Chart 1 of Pain (2003) reports the stock of loan loss provisions (as a percentage of total lending) of the largest UK banks over the years 1982-2000. The biggest source of losses was unconnected with the UK economy and property cycle: from the early 1980s Latin American and other overseas exposures of Lloyds, Midland and Standard Chartered (resulting in cumulated loan loss provisions of $9 \%, 7 \%$ and $6 \%$ of loan assets respectively). Barclays did not have the same substantial losses on international exposure in the 1980s, but in 1991-93 it accumulated loan loss provisions of close to $4 \%$ of its total lending, much of this arising from its UK commercial property exposures. The accumulated provisions of other UK banks were around one half of those of Barclays. The overall level of loan loss provisions in UK domestic banking were broadly similar, as a proportion of total lending, in 1991-1993 to the level of loss provisions reported in our Table 3 for the period 2008-2012.

While Barclays was hit especially hard, the magnitude of the commercial property lending boom appears to have been slightly smaller in the early 1990s than in the 2000s (our Figure 5). Total non-household real estate related lending increased from around $2 \%$ of GDP in 1986 to $8 \%$ of GDP in 1991; this compares with a rise of this lending category in the later commercial property boom from around 7\% of GDP in 1997 to 15\% of GDP in 2007.

While the problems in commercial property appear slightly smaller in 1991-1993 than in 2007-2012, this is not true of residential mortgage lending, Chart 2 of Pain (2003) reports 
the ratio of the stock of loan loss provisions to loans of the four largest UK mortgage banks. These rose to nearly $1.75 \%$ of lending (Alliance and Leicester) and around $0.8 \%$ of lending for the other three mortgage banks (Halifax, Abbey National and Northern Rock). Thus residential mortgage loan losses were much more severe in 1991-1993 than in the most recent mortgage market downturn of 2007-2012, most obviously because of the policy of maintaining high levels of interest rates in 1990-1992 to maintain UK fixed exchange in the European ERM.

\section{Summary and conclusions}

This paper has examined the expansion of credit prior to the financial crisis of 2007-2009 and the subsequent loan losses in UK sterling lending. A central question we have addressed is the role of new forms of intermediation ('shadow banking') and new credit instruments. We have reviewed the literature on shadow banking (Section 2); examined magnitude, financing and subsequent losses on the credit expansion of UK banks and the role played in this episode by shadow banks (Section 3) and provided a brief comparison with the earlier episodes of property related credit losses in UK domestic lending in 1973-75 and 1991-93 (Section 4).

We draw a distinction between 'old' shadow banking, taking funds from the established banking system, from 'new' shadow banking, using the modern tools of securitisation and credit risk transfer in order to create money-like substitutes for traditional bank deposits and hence disintermediate entirely from the established banks. We argue (Section 2) that while 'new' shadow banking of this kind played an important role in the US, by-passing commercial bank intermediation, it did not operate in this way in the markets for Euro and sterling lending. The only element of the 'new' shadow banking, of the kind described by Gorton and Metrick (2010) relevant to UK domestic (sterling) lending was the extensive use of securitisation, especially of residential mortgages, in the years preceding the crisis but these securitisations were all conducted by established UK banks, not by competing shadow banks.

Bank of England statistics reveal that residential mortgage lending led to relatively modest losses for UK banks in the period 2008-2013. Losses on sterling exposures emerged instead, 
primarily from lending secured on commercial property and unsecured personal lending, with most of the increase in losses associated with commercial property. This was a property boom (as documented by Benford and Burrows (2013b) commercial property lending increased to about two-thirds of total UK bank lending to the non-bank corporate sector (by UK owned and foreign banks)) followed, subsequently, by substantial loan losses.

A form of 'old' shadow banking played some role in this boom and bust, with real estate investment trusts and other specialised real estate funds investing in commercial property. In this respect the most recent episode of loan losses has some parallel to the UK lending losses of 1973-75, discussed in our Section 4, in which smaller 'secondary banks', drawing funding from larger established banks, and investing substantial funds secured on commercial property. There are also parallels with the UK in 1991-1993 (the end of the Thatcher-Lawson boom) where again much of the lending was secured on property with banks relying on market based valuation of the underlying collateral.

This does not mean that 'new' shadow banking played no role in the recent UK credit expansion or had no impact on UK banks. Royal Bank of Scotland, Barclays and HSBC were also active investors in offshore US dollar shadow banking, with substantial holdings and large subsequent trading losses on US dollar RMBS, CDOs and other structured credit instruments. Securitisation of residential mortgages also helped fund what now appear as unwise extension of credit into other more risky areas of lending, notably commercial property. The loss of confidence and resulting collapse in the marketability of residential mortgage backed securities during the crisis then had a further immediate impact, starving UK banks of liquidity, most notably in the failure of Northern Rock in September 2007. Apart though from this novelty, the widespread use of securitisation to fund loan expansion, this was a very old-fashioned banking crisis. 


\section{References}

Adrian, Tobias, and Hyun Song Shin. 2010. "The Changing Nature of Financial Intermediation and the Financial Crisis of 2007-09." FRB of New York Staff Report, (439).

- - Adrian, Tobias, and Hyun Song Shin. 2009. "The Shadow Banking System: Implications for Financial Regulation." SSRN Electronic Journal (July 1). doi:10.2139/ssrn.1441324. http://papers.ssrn.com/abstract=1441324.

- - . 2010. "The Changing Nature of Financial Intermediation and the Financial Crisis of 2007-09." Staff Reports. New York. http://www.newyorkfed.org/research/staff_reports/sr439.html.

Alba, Pedro, Leonardo Hernandez, and Daniela Klingebiel. 1999. "Financial Liberalization and the Capital Account: Thailand, 1988-97". The World Bank.

Ashcraft, Adam B, and Til Schuermann. 2008. "Understanding the Securitization of Subprime Mortgage Credit". Staff Report, Federal Reserve Bank of New York.

Benford, James, and Oliver Burrows. 2013. "Commercial Property and Financial Stability." Bank of England Quarterly Bulletin (1): 48-58. http://www.bankofengland.co.uk/publications/Documents/quarterlybulletin/2013/qb130105. pdf.

Bradshaw, Keith. 2004. "Informal Lenders in China Pose Risks to Banking System." New York Times. http://www.nytimes.com/2004/11/09/business/worldbusiness/09yuan.html?pagewanted=prin t\&position=\&_r=0.

Brunnermeier, M. K., and L. H. Pedersen. 2008. "Market Liquidity and Funding Liquidity." Review of Financial Studies 22 (6) (November 26): 2201-2238. doi:10.1093/rfs/hhn098. http://rfs.oxfordjournals.org/content/22/6/2201.short.

Charumilind, Chutatong, Raja Kali, and Yupana Wiwattanakantang. 2006. "Connected Lending: Thailand before the Financial Crisis*." The Journal of Business 79 (1): 181-218.

Davis, E Philip, and Haibin Zhu. 2004. "Bank Lending and Commercial Property Cycles: Some CrossCountry Evidence". 150. Working Paper. BIS working paper.

Financial Stability Board. 2013. "Global Shadow Banking Monitoring Report 2013." http://www.financialstabilityboard.org/publications/r_131114.htm.

Frydman, Carola, Eric Hilt, and Lily Y Zhou. 2012. “Economic Effects of Runs on Early'Shadow Banks': Trust Companies and the Impact of the Panic of 1907". National Bureau of Economic Research.

FSA. 2010. "The Prudential Regime for Trading Activities". 10/4. Discussion Paper. http://www.fsa.gov.uk/pubs/discussion/dp10_04.pdf.

Goodhart, Charles, and P J R Delargy. 1998. "Financial Crises: Plus Ça Change, plus C'est La Même Chose." International Finance 1 (2): 261-287.

Gorton, Gary. 2009. "The Subprime Panic*." European Financial Management 15 (1): 10-46. 
Gorton, Gary B, and Andrew Metrick. 2009. "Haircuts". 15273. Working Paper. National Bureau of Economic Research.

Gorton, Gary B. 2010. Slapped by the Invisible Hand: The Panic of 2007. Oxford University Press. http://books.google.com/books?id=8mExl4boLqIC\&pgis=1.

Gorton, Gary B., and Andrew Metrick. 2010. "Regulating the Shadow Banking System." SSRN Electronic Journal (October 18). doi:10.2139/ssrn.1676947.

http://papers.ssrn.com/abstract=1676947.

Gorton, Gary, and Andrew Metrick. 2010. "Regulating the Shadow Banking System." Brookings Papers on Economic Activity 2010 (2): 261-297. doi:10.1353/eca.2010.0016.

http://muse.jhu.edu/content/crossref/journals/brookings_papers_on_economic_activity/v201 0/2010.2.gorton.html.

- - . 2012. "Securitized Banking and the Run on Repo." Journal of Financial Economics 104 (3) (June): 425-451. doi:10.1016/j.jfineco.2011.03.016.

http://linkinghub.elsevier.com/retrieve/pii/S0304405X1100081X.

He, Dong, and Robert N. McCauley. 2010. "Offshore Markets for the Domestic Currency: Monetary and Financial Stability Issues". 02/2010. SSRN Electronic Journal. Working Paper. doi:10.2139/ssrn.1699740. http://papers.ssrn.com/abstract=1699740.

Hoggarth, Glenn, and Farouk Soussa. 2001. "Crisis Management, Lender of Last Resort and the Changing Nature of the Banking Industry." Financial Stability and Central Banks. London: Routledge for CCBS and the Bank of England.

Jackson, Patricia. 1996. "Deposit Protection and Bank Failures in the United Kingdom." Bank of England Financial Stability Review (1): 38-43.

Janssen, Norbert. 2009. "Measures of M4 and M4 Lending Excluding Intermediate Other Financial Corporations." Bank of England Monetary \& Financial Statistics (May): 1-4. http://www.bankofengland.co.uk/statistics/Documents/ms/articles/art1may09.pdf.

Kaminsky, Graciela L, and Carmen M Reinhart. 1999. "The Twin Crises: The Causes of Banking and Balance-Of-Payments Problems." The American Economic Review 89 (3) (June 1): 473-500. doi:10.2307/117029. http://www.jstor.org/stable/117029.

Leightner, Jonathan E, and C A Lovell. 1998. "The Impact of Financial Liberalization on the Performance of Thai Banks." Journal of Economics and Business 50 (2): 115-131.

Logan, Andrew. 2000. "The Early 1990s Small Bank' Crisis: Leading Indicators." Bank of England Financial Stability Review (8): 80-82.

McCulley, Paul. 2007. "Teton Reflections." Pimco Global Central Bank Focus.

McGuire, Patrick, and Goetz Von Peter. 2009. "The US Dollar Shortage in Global Banking." BIS Quarterly Review, March.

Milne, Alistair. 2009. The Fall of the House of Credit. Cambridge UK: Cambridge University Press. http://www.cambridge.org/gb/knowledge/isbn/item2428039/?site_locale=en_GB. 
Milne, Alistair, and Geoffrey E Wood. 2008. "Banking Crisis Solutions Old and New." Federal Reserve Bank of St. Louis Review 90 (September/October 2008).

Moen, Jon, and Ellis W Tallman. 1992. "The Bank Panic of 1907: The Role of Trust Companies." The Journal of Economic History 52 (03): 611-630.

Pain, Darren. 2003. "The Provisioning Experience of the Major UK Banks: A Small Panel Investigation". 177. Working Paper.

Pozsar, Zoltan, Tobias Adrian, Adam B. Ashcraft, and Haley Boesky. 2010. "Shadow Banking". 458. SSRN Electronic Journal. Staff Report. doi:10.2139/ssrn.1645337. http://papers.ssrn.com/abstract=1645337.

Pozsar, Zoltan, and Manmohan Singh. 2011. "The Nonbank-Bank Nexus and the Shadow Banking System" (December 1). http://papers.ssrn.com/abstract=1971440.

RBS. 2009. "Annual Report and Accounts, 2008."

Reid, Margaret. 1982. The Secondary Banking Crisis, 1973-75: Its Causes and Course. London and Basingstoke: Macmillan.

Reinhart, Carmen, and Kenneth Rogoff. 2009. This Time Is Different: Eight Centuries of Financial Folly. Princeton University Press. http://www.amazon.co.uk/This-Time-Different-CenturiesFinancial-ebook/dp/B004EYT932/ref=sr_1_1?ie=UTF8\&qid=1404847123\&sr=8$1 \&$ keywords=this+time+is+different+rogoff.

Singh, Manmohan. 2010. "The Sizable Role of Rehypothecation in the Shadow Banking System." SSRN Electronic Journal (September 2). doi:10.2139/ssrn.1670740. http://papers.ssrn.com/abstract=1670740.

Singh, Manmohan, and James Aitken. 2009. "Deleveraging after Lehman -- Evidence from Reduced Rehypothecation". 09/42. Working Papers. http://papers.ssrn.com/abstract=1366171.

United Dominions Trust Ltd v. Kirkwood BT - QB. 1966, 2431.

Vander Weyer, Martin. 2000. Falling Eagle: The Decline Of Barclays Bank. W\&N.

http://www.amazon.co.uk/Falling-Eagle-Decline-Barclays-Bank/dp/0297644068. 